\title{
The Image of Man in the Economic Sciences In Light of the Financial Crisis and Recent Research Results
}

\author{
Christian A. Conrad ${ }^{1}$ \\ ${ }^{1}$ University of Applied Science HTW at Saarbrücken, Germany. \\ Correspondence: Christian A. Conrad, University of Applied Science HTW, Waldhausweg 14, 66123 Saarbrücken, \\ Germany.
}

Received: November 26, 2015

Accepted: December 8, $2015 \quad$ Available online: January 6, 2016

doi:10.11114/aef.v3i1.1285

URL: http://dx.doi.org/10.11114/aef.v3i1.1285

\begin{abstract}
The image of Man in the Economic Sciences is examined in this paper from the perspective of behavioral economics and expanded using new interdisciplinary research findings. Experiments show that there are many people who selflessly do good deeds and feel better for doing so, not worse. This demonstrates a selfless motivation that contradicts the theory of utility maximization, or the concept of homo economicus. The fact that selfless, or even self-sacrificing, acts exist shows that such ethical behavior is part of human behavior. The experiments also show the influence of group behavior on economic decisions, which has been heretofore neglected in economic science. Not bad characters but moral hazards like unilateral compensation schemes are to blame for the subprime crisis. However teaching of ethical values is also needed.
\end{abstract}

Keywords: view of Man, homo economicus, behavioral economics, financial crisis, history of economic thought, moral hazards

JEL Classification: A20, B10, G01, G02

\section{Introduction}

The subprime crisis can be considered the epitome of the ethical failure of our modern economy. Everything came together, and many saw in the crisis the final act of our "turbo capitalism", the limitless enrichment of the few at the expense of society, which almost lead to a total collapse of the financial system (Dahrendorf, 2009). Unmoral aspiration for enrichment of managers was common in the subprime crisis. Does the manager behave unethically on the cost of its employer and the society? Are the bad characters of bank managers responsible for the financial crisis? Is Man its own enemy as he maximizes its benefit on the cost of others (homo homini lupus)?

This paper examines the image of Man in the economic sciences from the perspective of behavioral economics and expands that image using new interdisciplinary research findings. The main question is whether people consciously choose to behave ethically, even if doing so would be to their disadvantage. First we will analyze the economic assumption of homo economicus as an egoistic, utility-maximizing individual and then we will revisit Adam Smith's assumed egoistic utility-maximization via the "invisible hand." After that we will look at Man as a social animal in consideration of new knowledge from experiments, which also brings both egoist economic assumptions about behavior and utility maximization into question. In our conclusion we will compare the results of new research with economic behavioral assumptions and combine them into a new image of Man and look for the ethical reasons for the financial crisis.

\section{The classical view of Man: Homo economicus}

Macroeconomics uses a simplified model of humanity to represent economic actors, namely homo economicus, an egoistic creature Weber explains the reduction to rational goal-oriented action as simplified behavioral assumptions by giving examples of exceptions to rational behavior, such as stock market panic (Weber, 1922).

According to F. A. Hayek the term homo economicus goes back to John Stuart Mill and Utilitarianism (Hayek, 1971). Mill describes his view of Man as follows:

"It is concerned with him solely as a being who desires to possess wealth, and who is capable of judging of the comparative efficacy of means for obtaining that end. It predicts only such of the phenomena of the social state as take place in consequence of the pursuit of wealth. It makes entire abstraction of every other human passion or 
motive..." (Mill, 1844).

Homo economicus is like a computer, or a being that only acts rationally (Principle of Rationality) as a machine would. This ideal actor has given preferences, and thus a constant utility function. Such assumptions have the advantage that human behavior would change only if the basic parameters for a decision changed (Franz, 2004; Göbel, 2010). Assuming a given degree of information, human beings would always choose the option that maximizes their gain (Principle of the Individual), making their decisions mathematically predictable (Erlei, Leschke, \& Sauerland, 1999). Current economic thinking handles market failure as a human failure only marginally, if it means rejecting the Rationality Theory of homo economicus. But even then human behavior is deterministic based on the assumptions of how they behave irrationally. On the other hand, it means that homo economicus not only leaves the benefit to others out of the equation but that he would even commit amoral acts to achieve his goal of maximizing his own advantage, including lying, betraying and other immoral acts (Milgrom \& Roberts, 1992).

The theoretical homo economicus is a shallow image. When societal influences are not part of the equation, such an actor is represented as being purely psychological, not sociological. Mill considered people sociological, however:

"The deeply rooted conception which every individual even now has of himself as a social being, tends to make him feel it one of his natural wants that there should be harmony between his feelings and aims and those of his fellow creatures. If differences of opinion and of mental culture make it impossible for him to share many of their actual feelings-perhaps make him denounce and defy those feelings- he still needs to be conscious that his real aim and theirs do not conflict; that he is not opposing himself to what they really wish for, namely their own good, but is, on the contrary, promoting it. This feeling in most individuals is much inferior in strength to their selfish feelings, and is often wanting altogether. But to those who have it, it possesses all the characters of a natural feeling. " (Mill, 1863).

If we take societal mores for human behavior into consideration, the resulting decisions change. These mores are societal norms that dictate to the members of a society how they should act in order to benefit the society and not harm it. Societal norms and values can be chosen consciously by the individuals or inculcated socially. Societal sanctions in the case of norm infractions can make certain decision alternatives seem to be more utility maximizing even if they bring fewer individuals more advantage than others (Föhr \& Lenz, 1992). The term gain is to be understood as net individual advantage, in other words profitable gain reduced by losses from social sanctions. On the flip side, sanctions prevent decision alternatives that would maximize the individual's gain at the cost of society. Sociology refers to motive/norm conflicts in this context, because an individual's need conflicts with the norm. Societal norms have rarely been taken into consideration by economic science, if at all.

The same is true for ethical values, although the term "gain" applies even less. The need that many people feel to do good for other people only indirectly provides a gain, by satisfying an existing subjective need. Everything that a person wants and gets could be described as a gain (Hausmann \& McPherson, 2006), but additional benefit must also be objectively comprehensible to a third party. The fairy tale "Hans in Luck" by the Grimm Brothers (1819) illustrated how a person can feel better subjectively, even though their objective gain has diminished. The term "gain" in this context is really too restrictive, as one can really only speak of fulfilling a need. Economic decision-making theory needs to be expanded to include this concept. To sacrifice something for others may be rare, but it is a very well-known human phenomenon. To sacrifice would then indicate following the dictates of a need to help others, even if it reduces one's own objective advantage. This is exactly what earns our admiration and what many religions, including Christianity, demand of people; "It is better to give than to receive." The moral of the fairy tale is that Hans minimizes his objective gain and maximizes his subjective happiness. We need to speak more generally of happiness maximization when examining human motivations. The idea that having goods from the economy alone does not bring happiness is clear once goods have been acquired. That happy feeling does not usually last very long, and in the end the goods only fulfill material needs.

Jeremy Bentham, James Mill and his son John Stuart Mill, the main founders of Utilitarianism, grew apart over time. Utility maximization is now understood exclusively in relation to material gain. Happiness is closer to Bentham's thinking, as he considered pain and pleasure:

"Nature has placed mankind under the governance of two sovereign masters, pain and pleasure. It is for them alone to point out what we ought to do, as well as to determine what we shall do. On the one hand the standard of right and wrong, on the other the chain of causes and effects, are fastened to their throne. They govern us in all we do, in all we say, in all we think: every effort we can make to throw off our subjection, will serve but to demonstrate and confirm it. In words a man may pretend to abjure their empire: but in reality he will remain subject to it all the while. The principle of utility recognizes this subjection, and assumes it for the foundation of that system, the object of which is to rear the fabric of felicity by the hands of reason and of law." (Bentham, 1789).

For Bentham, happiness could arise from things such as sensory pleasure, a good reputation, wealth, power, or charitableness, but also negatively connoted traits such as malevolence. Pain might result from privation, a bad reputation, 
enemies, but potentially also from charitableness, piety or malevolence. John Stuart Mill includes not only desire in the pursuit of happiness but also the pursuit of honor, duty, and morality. Whoever rejects Utilitarianism because they reject the pursuit of happiness underestimates humanity. People search for happiness through their desires, but also through dignity:

“... but its most appropriate appellation is a sense of dignity, which all human beings possess in one form or other, and in some, though by no means in exact, proportion to their higher faculties, and which is so essential a part of the happiness of those in whom it is strong..." (Mill, 1863).

A person's self interest, thus the basis for being happy, can be found in the pleasure derived from understanding and morality. According to Mill, there are moral and immoral pleasures or perceptions of happiness, which is why people must question their interests and adjust their motives to their ethical views. (Mill, 1992). Utility maximization must therefore be understood as pleasure maximization and not solely as the maximization of material gain.

As opposed to the economic theory of homo economicus the information processor, social psychology considers people to be decision-making problem simplifiers. To this end people use patterns, created from their impressions and experiences. Social psychology has used several interesting experiments to show the influence of patterns. Pre-determined thought structures and ways to solve problems (behaviors) help to call up patters and information quickly. Over-confidence can also be an issue with thinking. It has been shown that people do not have the abilities of a homo economicus (Jonas, Stroebe \& Hewstone, 2007; Fehr \& Fischbacher, 2003; Fehr, Gächter \& Fischbacher, 2001; Frank, 2004; Frank, 1988, Gürerk, Irlenbusch \& Rockenbach, 2006). New Behavioral Finance agrees (Conrad, 2005).

According to social psychology, cultural and social factors influence human behavior, which is why it deviates from the homo economicus stereotype. Examples include various gestures and the strongly self-centered Western cultures as opposed to Asian cultures. It is also important to know how people adapt to cognitive dissonance, which might be created by an immoral environment. The Asch Conformity Experiment proved that individuals even adopt a false group opinion if the group presents its view with self-confidence. People take on roles within groups that influence their behavior. Individuals adapt to the group in order to gain social recognition (social comparison process or aspiring to conformity). It is assumed on the other hand, that only the individual influences the behavior of homo economicus. Norms create moral behavior, as has been shown in experiments (Asch, 1951; Jonas, Stroebe \& Hewstone, 2007; Fehr \& Fischbacher, 2003; Fehr, Gächter \& Fischbacher, 2001; Frank, 2004; Frank, 1988, Gürerk, Irlenbusch \& Rockenbach, 2006). The simplified human model of homo economicus is legitimate. Rational, informed and balanced action generally does bring advantages. The assumptions behind homo economicus become problematic when economic science forgets that they are dealing with a model and treat it as reality:

"Not that any political economist was ever so absurd as to suppose that mankind are really thus constituted, but because this is the mode in which science must necessarily proceed." (Mill, 1844)

An interesting neurological experiment was conducted in 2003 that showed homo economicus to be a fiction, and the press gave its conclusions much attention. The Ultimatum Game was conducted in the laboratory of Princeton University by Alan Sanfeys (Sanfey et al., 2002; Kraft, 2006).

\section{Falsely Understood Egoism}

Perhaps the lack of ethics and morals of many managers comes from a false understanding of the economic bible "Wealth of Nations," by Adam Smith, or at least a very abbreviated and thus misleading representation of his ideas as presented in economic education. The brilliant idea of Adam Smith was how human self-interest is directed toward the common good through the "invisible hand" of the market. Even bad people thus serve the common good, as Hume commented. The law of the market functions as an ethical guideline thus (Starbatty, 1999):

"...it is not from the benevolence of the butcher, the brewer, or the baker, that we expect our dinner, but from their regard to their own interest." (Smith, 1776).

The idea of an invisible hand can be traced back to "The Fable of the Bees" by Mandeville:

"The worst of all the Multitude Did something for the Common Good." (Mandeville, 1732)

Mandeville had already seen the danger than self-interest can pose to society:

"So vice is beneficial found, when it's by justice lopt, and bound; Nay the people would be great; as necessary to the state; As hunger is to make them eat; Bare virtue can't make nations live; In Splendor; they, that would revive A Golden Age must be as free For Acorns, as for Honesty." (Mandeville, 1732).

"By pursuing his own interest he frequently promotes that of the society more effectually than when he really intends to promote it." (Smith, 1776).

It almost seems as though many managers take this as a free pass to limitless pursuit of their own interest, as though they 
understood it as egoism at the cost of others. The second central work of the Scottish moral philosopher Adam Smith, "Theory of Moral Sentiments" is almost never mentioned. Here we find quite different quotes:

"How selfish soever man may be supposed, there are evidently some principles in his nature, which interest him in the fortune of others, and render their happiness necessary to him, though he derives nothing from it except the pleasure of seeing it." (Smith, 1759).

According to Smith, people have a highly developed conscience that functions as an internal moral judge. He accords people the capacity of compassion and sympathy with other people, like Schopenhauer (Schopenhauer, 1840) and Hume:

"We are certain, that sympathy is a very powerful principal in human nature." (Hume, 1739).

They can empathize with the interests and needs of their fellow humans, and must therefore weigh them in their conscience against their own self-interest. They are helped in this by an imaginary, objective third-person opinion derived from the question of how an impartial third party would decide. The principle of rational thinking is the basis for weighing the various interests. This capacity of a human conscience is generally credited to God or generally to human rationality. The individual is part of the natural whole and responsible for his or her own decisions. Responsibility and freedom are natural and God-given. Smith believes a truly uninvolved and objective third party's opinion is necessary to determine whether an action is morally and ethically acceptable. This impartial observer takes on the task of social corrective, which is comparable to Immanuel Kant's categorical imperative. Always act in such a way, that the basis for decisions could be the principle behind a general rule, the behavior could always be acted upon by all people and for the good of society (Nass, 2002).

Adam Smith was aware that the invisible hand is not sufficient to protect the common good from damage done by an individual. He stressed the need for an economic and structural system that included protection for the common good. Enrichment of the individual at the expense of the common good cannot be tolerated by a society for various reasons. Besides the damage sustained by the national economy, such behavior supplants the system. According to Smith, trade can develop via markets to the benefit of all people, thus creating wealth, only when the legal system is functional and there is trust in the supremacy of the state (Smith, 1776).

\section{Individualism versus Collectivism}

The trigger or tit-for-tat games describe the underlying conflict between individual and collective rationality. In the prisoner's dilemma, maximizing individual utility at the cost of third parties is in direct opposition to collective benefit through social gains, e.g. access to collective goods such as a clean environment. In the Sixties, Rapoport and Chammah (1970) used experiments to show that cooperation begins if games such as the prisoner's dilemma are played repeatedly. Based on computer simulations, Robert Axelrod later analyzed the conditions under which cooperation comes into being. In this context the tit-for-tat strategy suggested by Rapoport maximized results. This strategy has its strengths and weaknesses. The strategy says to play fair and never fleece or injure your opponent. Only if your opponent behaves uncooperatively, should you do the same. This strategy maintains the possibility for opponents to gain more only as long as they behave cooperatively, and to gain less if they are uncooperative. The motivation is thus to be cooperative and receive sanctions if you are not. The regulated sanctions would be the norms of the game. Exploitative strategies harm one's self and the other, because the gains from cooperation disappear. In the end, maximizing individual gain at the cost of another party means less net utility. Rapoport calls the principle behind this strategy "in weakness is strength," and recommends it as a leitmotif in his studies on arms races and conflict avoidance (Rapoport \& Chammah, 1970; Axelrod, 1987; Schwaninger, 2008).

Reciprocity was also observed in animal world. For instance researchers at the University of Bern in Switzerland found out that rats selflessly help even unknown members of their species if they had been helped in their own past. This allows us to assume that a willingness to help proved beneficial to evolutionary goals. The more help the rat had experienced, the more help it was willing to give (Rutte \& Taborsky, 2007; Dolivo \& Taborsky, 2015; Conrad, 2010).

The issue of cooperation benefits from public goods can also be illustrated with a game. A public goods game consists of say 5 people who must each pay $10 \$$ into a pot. If everyone pays in, the money in the pot doubles, which is meant to represent the added value of public goods. If not everyone pays in, the public good is not created and the sum is divided by five and paid back out. In the worst case scenario a player could pay in $10 \$$ and get back $2 \$$. The experiment shows that in the case of public goods made available, the initial trust decreases over several rounds of play because of the free-rider issue (Holzmann, 2015).

In a public goods game, $40-60 \%$ of players are cooperative at the beginning. This behavior decreases when they notice that they are hurting themselves and the cooperative good is not being created. They then play up to ten rounds of anonymous play cooperatively and then become uncooperative (Fehr \& Fischbacher, 2003). There is always a base group of players who insist on being uncooperative and try to maximize their gain to the detriment of the other players. These free riders make up about one third of players. Altruistic rewards and punishments, which are also at the cost of the 
participants, can discipline the free riders into more cooperative behavior, which can allow the public good to be created to everyone's benefit (Fehr \& Fischbacher, 2003; Fehr, Gächter, Simon \& Fischbacher, 2001).

Gürerk, Irlenbusch and Rockenbach (2006) and other authors emphasize the role of so-called "strong reciprocators," meaning players that punish uncooperative free riders even though it is to their detriment: "Strong reciprocators bear the cost of rewarding or punishing even if they gain no individual economic benefit whatsoever from their acts." (Fehr \& Fischbacher, 2003). Emotions motivate the strong reciprocators to set the norms despite the loss they may suffer. Altruistic sanctioning of uncooperative behavior can be motivated by gratefulness, or a desire for retaliation. Without emotions no one would punish another to their own detriment. Getting upset over uncooperative behavior creates a sense of gratification and thus a net benefit for inflicting the punishment, which makes altruistic punishments possible (Föhr \& Lenz, 1992; Frank, 1988); Frank, 2004).

Fehr and Fischbacher showed that over $60 \%$ of neutral third parties will intervene in the case of game behavior perceived as unfair and uncooperative to impose fairness and cooperation even if it puts them at a disadvantage (Fehr \& Fischbacher, 2003). We are talking about the sense of justice that makes us human. The sense of justice is why cooperative behavior in a group gets enforced. There are sanctions meted out, even though doing so requires effort and the sense of justice unites the group in its behavior.

These games also show the importance of societal sanctions (norms), learning and socialization. The great majority of players enter the game in a spirit of cooperation, but they are willing to change that behavior if the advantages of cooperating turn to disadvantages. Such an experience is also part of the learning process, such as the role that reputation plays. If there is an option to switch to a game where sanctions are possible, it will be taken in order enjoy public goods. With time the players are able to establish norms, allowing punishments to diminish greatly (Fehr \& Fischbacher, 2003). The tit-for-tat strategy was observed during these games as well. Thus most players saw their cooperative contribution increase along with that of the other players (Falk, 2003; Fehr, Gächter \& Fischbacher, 2001).

It maximizes one's advantage to be uncooperative when playing just one round of the game, yet cooperative if playing several rounds. In other words, if the other players can neither defend themselves nor retaliate it is advantageous to fleece one's opponents, behaving unethically to the detriment of others, but not if they are able to defend their interests.

It is therefore not surprising that many ethical misdeeds have taken place within the finance sector within the last few years, since the games are generally played with just one round. No one even knows their business partner on the stock market. The bad subprime credits were mostly sold through the stock markets. If the buyer could have prosecuted the seller, the worthless sales would never have reached such a level because it would not have maximized utility to do so. Anywhere there is a long-term business relationship, or legal damage compensation is easy to obtain, it is not utility maximizing to injure a business partner.

We can observe however, that business is sometimes conducted such that this utility-maximizing strategy is contradicted. There are fields of u-pick flowers, and self-serve newspaper kiosks in the city, where one can cut flowers or take a paper without paying for it. Not paying would be the rational utility maximization strategy, since the "buyer" would not fear any reprisal. These offers exist nonetheless, which means that many people behave ethically and socially, instead of rationally utility-maximizing.

There have been several studies on human behavior using errant pieces of mail. Letters with postage were tossed into a mailbox at a rate of almost 80\%. If the letter contained money, still more than 50\% were forwarded (Lück \& Manz, 1973). In an experiment in which a wallet was placed in the letter, passersby in New York forwarded untouched wallets at a rate of almost 50\% (Hornstein, Fisch \& Holmes, 1968). Gneezy's (2005) sender-receiver game experiment using students showed that many people tend towards the truth, even if they do worse because of it. Asymmetrical information is thus not always used to one's advantage.

The results of these experiments can be explained by altruism, honesty as a human character trait or by corresponding social norms. That the addressees of the letter were unknown, and thus the finder could not identify with them, speaks for the explanation that moral behavior derives from norms (Hausmann \& McPherson, 2006). On the other hand, there are no sanctions in this example that would create the norms, since the behavior was believed to be unobserved.

\section{Sense of Fairness or What Makes People Tick?}

Alan Sanfeys conducted the "Ultimatum Game" in the laboratory at Princeton University. Two subjects are told to divide $\$ 10$ amongst themselves. The first (proposer) get the whole amount and can decide how much he gives the other. The second (responder) can then decide whether he accepts or rejects the portion he is offered. If he rejects the offer, neither gets anything (Sanfey et al., 2002).

Rational behavior would dictate that the second subject agree to any amount offered. Regardless of how much he is given, he would still be better off than if he were to reject it and both get nothing. People apparently behave quite differently, 
however. If the offer is seen as too low, many subjects rejected the offer completely and preferred to have nothing. The Ultimatum Game was adapted and executed under competitive conditions with a proposer and several responders. Only the first responder to accept the proposer's offer received a payout. The responders accepted even very low offers in this situation (Holzmann, 2015; Roth, Prasnikar, Okuno-Fujiwara \& Zamir, 1991). Such a something or nothing situation is not comparable to the competition based on performance as per the do-ut-des principle of the markets. Brain activity values (MRT) showed that the lower the offer was, the more the prefrontal cortex (PFC), responsible for rational thinking, was overshadowed by the Insula, responsible for emotions. The interpretation of this experiment indicates that the positive decision to gain money was increasingly superimposed by the negative feeling of being treated badly by the other subject (Sanfey et al., 2002). The Ultimatum Game has existed since the 1980s (Güth, Schmittberger \& Schwarze, 1982).

This interesting neurological experiment from 2003 was lauded by the press for the realization that homo economicus is a fiction, yet the experiment can be interpreted differently if we take into account that humans are social animals, as Aristotle suggested (Aristoteles, 1944). We can interpret the second subject's rejection of an offer felt to be too low as an expression of the sense of fairness. It seems obvious that $\$ 10$ should be split evenly among equals with $\$ 5$ each. If we assume that humans are social animals descended from apes, we can call the behavior of rejecting a low offer irrational, yet goal-oriented and effective. How would such a group experiment play out in real life? By rejecting the offer, the second subject signals that he rejects the social behavior of the first subject as unfair. He is also showing the proposer that his behavior can have negative consequences for him in the group if the other members agree that he has violated a norm, namely how sustenance is divided within a group. This behavior is programmed into us as humans and could not be denied in another experiment with different parameters. The refusal to accept the amount could alternatively mean that the second subject wishes to signal the first that he is not willing to be disparaged in the group with a lesser share of sustenance, and that the first subject has maneuvered himself into a conflict situation with his offer and the second subject will get him back at the next opportunity regardless of the experiment (Conrad, 2010, Fehr \& Fischbacher, 2003).

A variant of the Ultimatum Game is the Dictator Game. In this game the second subject has no influence on the final distribution, rather he must accept what the first subject gives him. Here it would rationally maximize one's utility for the first subject to keep everything. The experiment shows however, that on average about $30 \%$ is given to the second subject, again showing an altruistic sense of justice (Holzmann, 2015).

Research on primates has also concluded that fairness is a central principle for creating cooperation in a group. Frans de Waal and Sarah Brosnan at Emory University in Atlanta conducted experiments with capuchin monkeys, in which different rewards - a grape or a cucumber - were given for the same effort. The monkeys refused the cucumber as a lesser reward for the same effort, leading De Waal and Brosnan to conclude that primates have an innate sense of fairness that has evolved to develop cooperation. Susan Perry from the Max Planck Institute for Evolutionary Anthropology in Leipzig also did experiments with capuchin monkeys and arrived at similar conclusions (Brosnan \& de Waal, 2003; Perry, 2003; Brosnan \& de Waal, 2014).

The experiment also shows the influence of group behavior on economic decisions, which has been heretofore neglected in economic science. Fairness as an ethical value has concerned people as long as they have existed. Fairness, or justice, is the objective of the basic normative principle of human co-habitation (principle of social behavior) (Höffe, 1997). This is the prerequisite for an individual to participate in the division of labor of a group. The individual will only adapt to group's demands and work cooperatively if his share from the labor distribution is felt to be fair. Without fairness there is no added value from labor distribution for our society and civilization (emergence).

Subjectively, fairness is understood as an ethical value. The classical world considered it a fundamental virtue as well as a guiding principle for action, which prevented any overreaching one's fellow humans. Even though there are no sanctioned norms, a righteous person behaves ethically by not taking advantage of others even when he has the opportunity; he in fact gives others their share.

\section{Conclusion}

What motivation for ethical behavior do we have? There are many people who selflessly do good deeds and feel better for doing so, not worse. This gives us a selfless motivation that contradicts the theory of utility maximization, or the concept of homo economicus. The fact that selfless, or even self-sacrificing, acts exists shows that such an ethic is not unrealistic. Volunteer work and individuals like Mother Teresa are clear examples. This behavior can be explained by a more general theory of maximizing happiness, which is behind theories like the Happiness Theory from Bentham and Mill. Many people are generally good, which is to say they have an ethical disposition.

Selfless acts generally garner prestige in a society, presenting another motivation for ethical behavior. Both motivations are bases for behavior relevant to the satisfaction of a person's basic needs, according to Maslow's (1943) hierarchy of needs. Beyond maximizing one's advantage, people need to feel a purpose in life. There are people who measure their 
benefit or value as a person by how beneficial they are to others. Behavioral theories have given too little consideration to intrinsic motivations until now. Here we are looking at an enlightened human ethos. People consciously behave ethically because they understand the importance of such behavior to society, or because they empathize with other people. Normally these motivations only become meaningful after all of one's basic needs have been met, and they cannot be presupposed for every person. Nonetheless, such ethical motivations must not be disregarded. Our representative democracy in fact demands altruistic behavior from people as a prerequisite to allowing delegates to represent the voter's interests. This expanded theory allows us to explain altruism, helping others and sympathy.

Sympathy is the basis for human existence, since help and consideration strengthen a society. In the social nature of humans there is a very great hidden strength. This social nature and the differences among people allow the existence of labor distribution and connected, complex processes. In connection with the advancement of the human brain, the social nature is a main reason why humans have a civilization level superior to other living beings. Ethical behavior as altruistic behavior in groups (morality) was thus an evolutionary advantage and can be seen as social capital. Social capital is all of the prerequisites for productivity a person has, but only in a group, thus social in the sense that it can only be realized within a society. The social added value can only be created with others. Morality reduces the transaction and control costs of social activities. From this background trust is nothing else than believing that someone will behave as expected without sanctions, thus cooperatively. If everyone behaved perfectly morally, most legal costs and other expenses created by the implementation of rights would disappear. The certainty of cooperative behavior coming from morality would stimulate economic decisions, in particular investment decisions that would otherwise not be made due to insecurity about the behavior of others and the rights to investment profits (asymmetric information). Morality thus increases the productivity of the economy (Conrad, 2010).

The genetic predisposition to cooperative behavior we have described is not sufficient on its own, however. Hobbes recognized that cooperative behavior must be worthwhile for the individual, who must also be able to count on it from others, since we would otherwise have anarchy. Luhmann (2000) considers trust to be a tool used to reduce the complexity of social interactions. Trust can only be ensured by a society rewarding cooperative behavior and punishing non-cooperative behavior. Without controls and sanctions there is no guarantee of fair, thus economically ethical, behavior.

Therefore a lack of financial regulation and moral hazards are extremely dangerous. The existing asymmetries of bonus compensation schemes have led to a divergence of interests between employees on the one hand and the health of financial institutions and other companies at large on the other hand. Remuneration and bonuses depend on short-term profitability, which increases share prices in the short-term, but not the long-term health of the company. In the financial system, investment managers increased the risks for their employer by buying highly profitable but risky assets and were rewarded with high bonuses, which led to the financial crisis in the long term. Without accountability variable compensation schemes become unilateral bonus maximation schemes with negative effects for the company and the principal. It means risking other people's money which will generally be abused unethically (Conrad, 2015).

Moreover people are influenced in their behavior by their view of the world. Ideas and attitudes, or moral values, must be shown by example and included in education. This makes schools of economic science particularly important. There are those who blame management training for catastrophes such as Enron, the subprime crisis etc. Thomas Lindsay, once Dean of the University of Dallas, points to studies before Enron that prove managers rarely fail economically or morally because of a lack of professional knowledge. What they are generally missing is what Aristotle calls "wisdom," to be understood as interpersonal capabilities and practical knowledge. In Lindsay's opinion the education for managers was excessively subject-oriented, and the moral capabilities of the students is almost completely lost through unadulterated profit maximization. Aristotle said that true leadership is based on the ability to recognize and serve the good of the community. To train these abilities one needs much more than a professional education, one needs instruction in history, philosophy, literature, theology and logic (Bennis \& O'Toole, 2005).

If households maximize their benefits and companies maximize their profits, it is economically efficient and economic science would consider this a goal for orientation. Successful businessmen always act to maximize profit. Whoever wants to be a successful businessman should act accordingly. Successful households also act to maximize benefits. Thus private persons should also act to maximize benefits. This is the world being taught to young students of economic science in the Western industrial countries. Many would say that this is how the world is, and people ruthlessly maximize their benefits. What about the idea that people are neither wholly good nor wholly bad - as this paper has shown - but they were only told to behave badly? The world would be worse than it had to be.

\section{Reference}

Aristoteles (1944). Politics.

http://www.perseus.tufts.edu/hopper/text?doc=Perseus:text:1999.01.0058:book=1:section=1253a. 
Asch, S. E. (1951). Effects of group pressure upon the modification and distortion of judgments. In Guetzkow, Harold (ed.). Groups, leadership and men; research in human relations, Oxford, 177-190.

Axelrod, R. (1987). Die Evolution der Kooperation, Munich 1987.

Bennis, W. G., \& O`Toole, J. (2005). How Business Schools Lost Their Way. Harvard Business Review, (May 2005), pp. 1-9. https://hbr.org/2005/05/how-business-schools-lost-their-way

Bentham, J. (1789). Introduction to the Principles of Morals and Legislation (1780, published1789). ed. by J. H. Burns/H.L.A. Hart (The Collected Works of Jeremy Bentham). 2. ed., Oxford 1996.

Brosnan, S. F., \& de Waal, F. B. M. (2003). Monkeys reject unequal pay. Nature, 425(September 18 ${ }^{\text {th }}$ ), $297-299$.

Brosnan, S. F., \& de Waal, F. B. M. (2014). Evolution of responses to (un) fairness. Science, 346(6207). 1251776, 314-320.

Conrad, C., A. (2010). Morality and Economic Crisis - Enron, Subprime \& Co., Hamburg 2010.

Conrad, C. A. (2015). Incentives, Risk and Compensation Schemes: Experimental Evidence on the Importance of Risk Adequate Compensation, in: Applied Economics and Finance, 2(2), 50-55.

Dahrendorf, R. (2009, July 12). Die verlorene Ehre des Kaufmanns. Tagesspiegel. http://www.tagesspiegel.de/wirtschaft/dahrendorf-essay-die-verlorene-ehre-des-kaufmanns/1555814.html.

Dolivo, V., \& Taborsky, M. (2015), Norway rats reciprocate help according to the quality of help they received. Biology Letters. 11:20140959. http://dx.doi.org/10.1098/rsbl.2014.0959

Erlei, M., Leschke, M., \& Sauerland, D. (1999). Neue Institutionenökonomik, Stuttgart 1999.

Falk, A. (2003). Homo oeconomicus versus Homo recipocans: Ansätze für ein neues Wirtschaftspolitisches Weltbild? Perspektiven der Wirtschaftspolitik, 4(2003), 141-172.

Fehr, E., \& Fischbacher, U. (2003). The nature of human altruism. Nature, 425(23), 785-791.

Fehr, G., \& Fischbacher, U. (2001). Are people conditionally cooperative? Evidence from a public goods experiment. Economics Letters, 71, 397-404.

Föhr, S., \& Lenz, H. (1992). Unternehmenskultur und ökonomische Theorie. In Staehle, W. H., \& Conrad, P. (ed.). Managementforschung, 111-162. Berlin.

Frank, R. H. (1988). Passion within reason. The strategic role of the emotions, New York 1988.

Frank, R. H. (2004). What Price the Moral High Ground? Princeton 2004.

Franz, Stephan (2004). Grundlagen des ökonomischen Ansatzes: Das Erklärungskonzept des Homo Oeconomicus, Working Paper der Universität Potsdam. 2004-02. www.uni-potsdam.de/u/makrooekonomie/docs/studoc/stud7.pdf

Gneezy, U. (2005). Deception: The Role of Consequences, American Economic Review, 95(1), 384-394.

Göbel, E. (2010). Unternehmensethik, Stuttgart 2010.

Grimm Brothers (1819). Hans in Luck. http://www.authorama.com/grimms-fairy-tales-2.html

Gürerk, Ö. I., \& Rockenbach, B. (2006). The Competitive Advantage of Sanctioning Institutions. Science, 312 (April), 108-111.

Güth, W., Schmittberger R., \& Schwarze, B. (1982). An Experimental Analysis of Ultimatum Bargaining. Journal of Economic Behavior and Organization, 3(4), 367-388.

Hausmann, D. M., \& McPherson, M. (2006). Economic Analysis, Moral Philosophy, and Public Policy, Second Edition, Cambridge 2006.

Höffe, O. (1992). Einleitung. In Höffe, Otfried (ed.). Einführung in die utilitaristische Ethik, Klassische und zeitgenössische Texte. Edition. Stuttgart, 7-54.

Holzmann, R. (2015). Wirtschaftsethik, Wiesbaden 2015.

Hornstein, H. A., Fisch, E., \& Holmes, M. (1968). Influence of a model's feeling about his behavior and his relevance as a comparison other on observers' helping behavior, Journal of Personality and Social Psychology, 10(3), $222-226$.

Jonas, K., Stroebe, W., \& Hewstone M. (2007). Sozialpsychologie, Eine Einführung, 5, Edition. Heidelberg.

Kraft, U. (2006, March 23). Der Mensch - das emotionale Wesen, Handelsblatt. http://www.handelsblatt.com/technik/forschung-innovation/neurologieforschung-der-mensch-dasemotionale-wesen/ 2632378.html 
Lück, H. E., \& Manz, W. (1973). Die Technik der verlorenen Briefe - Ein neues Instrument verhaltensbezogener Einstellungsmessung? Zeitschrift für Soziologie, 2(4), 352-365.

Luhmann, N. (2000). Vertrauen: Ein Mechanismus der Reduktion sozialer Komplexität, Stuttgart 2000.

Mandeville, Bernard de (1732). The Fable of the Bees; or, Private Vices, Public Benefits, London 1714 (first edition 1714).

Maslow, A. H. (1943). A theory of human motivation. Psychological Review, 50(4), 370-396.

Milgrom, P., \& Roberts, J. (1992). Economics, Organization \& Management, Upper Saddle River NJ 1992.

Mill, J. S. (1844). Essays on Some Unsettled Questions of Political Economy, London 1844, http://www.econlib.org/library/Mill/mlUQP5.html (25.04.2015.)

Mill, J. S. (1863). Utilitarism. In Mill, John Stuart (2010). The Basic Writings of John Stuart Mill: On Liberty, The Subjection of Women and Utilitarianism, New York.

Mill, J. S. (1992). Utilitarismus. In Höffe, Otfried (ed.). Einführung in die utilitaristische Ethik, Klassische und zeitgenössische Texte. Edition, Tübingen, 84-97.

Nass, E. (2003). Der Mensch als Ziel der Wirtschaftsethik: eine finalethische Positionierung im Spannungsfeld zwischen Ethik und Ökonomie, Schöningh, Paderborn.

Perry, S. (2003). Social conventions in Wild White-faced Capuchin Monkeys: Evidence for Traditions in a Neotropical Primate, Current Anthropology, 44(2), 241-268.

Rapoport, A., \& Chammah, A. M. (1970). Prisoner's Dilemma - A Study in Conflict and Cooperation. 2. ed. University of Michigan Press: Ann Arbor.

Roth, A. E., Prasnikar, V., Okuno-Fujiwara, M., \& Zamir, S. (1991). Bargaining and Market Behavior in Jerusalem, Ljubljana, Pittsburgh, and Tokyo: An Experimental Study. American Economic Review, 81(5), 1068-1095.

Rutte C., \& Taborsky, M. (2007), Generalized reciprocity in rats. PLoS Biol, 5(7), 1421-1425.

Sanfey, A. et al. (2002). The neutral basis of economic decision-making in the ultimatum game. Science, 300 (2002), 1755-1758.

Schopenhauer, A. (1840). Preisschrift über die Grundlage der Moral. Hamburg.

Schwaninger, M. (2008). Anatol Rapoport (May 22, 1911-January 20, 2007). pioneer of systems theory and peace research, mathematician, philosopher and pianist. Wiley Online Library Systems Research and Behavioral Science, 24(6), 655-658.

Smith, A. (1759). The Theory of the Moral Sentiments. Edinburgh.

Smith, A. (1776). An Inquiry into the Nature and causes of the wealth of nations, Edinburgh 1776. http://www.econlib.org/library/Smith/smWN8.html

Starbatty, J. (1999). Das Menschenbild in den Wirtschaftswissenschaften. Tübinger Diskussionsbeiträge der Wirtschaftswissenschaftlichen Fakultät, 176, https://publikationen.uni-tuebingen.de/xmlui/handle/10900/47437.

Weber, M. (1922). Wirtschaft und Gesellschaft, Grundriss der verstehenden Soziologie, Edition. Tübingen.

\section{(cc) $\mathrm{BY}$}

This work is licensed under a Creative Commons Attribution 3.0 License. 